\title{
Implementing Fun Cooking Media in Healthy Food: A Computer-based Use
}

\section{Nur Riska ${ }^{1}$, Prasetyo Wibowo $\mathrm{Y}^{2}$, and Annis Kandriasari ${ }^{1}$}

${ }^{1}$ Culinary Arts Vocational Education Study Program, Faculty of Engineering, State University of Jakarta

${ }^{2}$ Computer Informatics Education Study Program, Faculty of Engineering, State University of Jakarta

\section{Abstract}

This paper analyzes an implementation of fun cooking in healthy food toward a computer-based use to increase the knowledge of students aged 5-6 years. Respondents were students of group B in Ikal 1 Kindergarten at East Jakarta, Kreativa Kindergarten at Bogor City, Generasi Bangsa Early Childhood Education Program, and An-Nashihin Kindergarten. Data analysis was done using qualitative analysis for quantitative data and qualitative analysis or inference (Z-test) for quantitative data in

Corresponding Author:

Nur Riska

n_riska@yahoo.com

Received: 11 January 2019

Accepted: 14 February 2019

Published: 25 March 2019

Publishing services provided by Knowledge E

(c) Nur Riska et al. This article is distributed under the terms of the Creative Commons

Attribution License, which permits unrestricted use and redistribution provided that the original author and source are credited.

Selection and Peer-review under the responsibility of the 3rd ICTVET 2018 Conference Committee.

\section{G OPEN ACCESS} order to analyze the results of a trial model using an experimental design. This research design used a two-group pretest-posttest. Paired Sample Test results obtained a $p$ value of 0.000 smaller than $0.05 . \mathrm{H}_{0}$ is rejected, and $\mathrm{H}_{1}$ is accepted. It means that there is significant influence between knowledge of students aged 5-6 years before and after implementing fun cooking media in healthy food toward a computer-based use. It has an average value of $96 \%$ which expects higher media effectiveness. $Z_{\text {count }}$ obtained -2.89 but $Z_{\text {table }}$ with $\alpha=0.05$ obtained -1.96 . In $Z$-counts $<-Z_{\text {table }}, H_{0}$ is rejected, and $\mathrm{H}_{1}$ is accepted. It means that there is a significant difference in the use of old media toward images and new media toward computer-based. In conclusion, the implementation of fun cooking in healthy food toward a computer-based use is better than image.

Keywords: implementation, fun cooking media, healthy food, computer-based

\section{Introduction}

In this technology development, we should use technology properly in order to help and facilitate various things, especially learning. We need a learning tool that can maximize the capture power of students to help children learn by seeing, hearing and doing. One of the technologies that continue to evolve and considers to provide fun learning is involving games. By using games, it combines song media, puzzles and becomes more enjoyable. Games will be beneficial if used positively. For instance, games as an edutainment media combine elements of education with entertainment or often called 
playing while learning [1]. Selecting games for children must adjust to their age in order to provide the right stimulus. So, the game has a positive impact on children's growth and development. The existence of negative elements that can be found easily in various places and forms, which are sometimes fooled by children's favorite characters. It must be filtering the games used by children. According to Costikyan (2004) in Martono, games are a form of art in which participants called players and make decisions to manage their resources through objects in the game to achieve goals. Also, the game is inherently interactive. This activity centered on an achievement both active actors and opponents according Crawford (2003) in Martono [2].

Based on the research results on100 kindergarten children of group B around \pm five years in Semarang, the average children played video games using electronic devices. For example, they played computers for 2-4 hours every day without playing outdoors and learning [3]. In qualitative methods, the observation results obtained that children can expand their knowledge by using computer games, learn a lot through their interaction with technology. So, it added insight and broaden their knowledge of technology development. In brief, children spent playing computer games more than doing other things such as learning and playing outdoors. They sit quietly at home rather than playing outdoors [4]. Then playing computer can be a learning medium and develop aspects of child development [5]. It supported by Tedjasaputra who said that the most popular playing activity for children aged $4-5$ years is amusement games. Four informants explained that children would be natural to eat when they play computer. They become more accessible to eat, but they do not eat by themselves. Also, playing the computer affect their sleep time. They want to sleep after playing computer. While children forget to take a bath, parents must remind them or turn off the electricity in order to stop playing the computer. Unlike SPC's sisters or brothers, playing computer is not a passive game. They use a computer to play Indian dance videos and adapt the movements in order to move their body actively [6].

In the first year research that has been done, the learning media said to be "Very Good" and "Enough." There is no negative response from students. The learning media of Fun Cooking media in the form of 3D animated video and video cooking healthy food are feasible and practical to be used as learning media on the material of balanced, healthy food and drinks [7]. Nutrition education through games is an effective way to increase children's knowledge about the importance of balanced nutrition. It evidenced in a study conducted in Medan regarding the effect of nutritional education on a balanced diet through game puzzles to increase the knowledge of elementary school children. The results indicate that nutritional education through puzzle games 
can increase school children's knowledge about balanced diet $(p=0.000)$. After nutrition education carried out through a puzzle, there were no more children in the category of unfavorable knowledge [8].

Based on the description above, researchers interested in applying an early childhood learning education game about healthy food toward computer-based. In digital games, computer games can enhance children's creativity and intellectuals. Games can be influential as a stimulus for brain development and knowledge of children. Related to learning activities, one of the learning media that is suitable to help preschoolers able to absorb knowledge without making children feel forced and depressed is using computer games as a medium of information for children's knowledge, considering preschoolers are ages play. Supported by the rapid development of information technology, the presence of computer games can be used as a learning medium for preschoolers. The games used for this research are PC games or computer games. In brief, it can use as a learning medium that contains information or learning material but still enjoyable. So, the researchers interested in researching implementation of fun cooking in healthy food toward a computer-based use to increase the knowledge of students aged 5-6 years.

\section{Methods and Equipment}

\subsection{Methods}

This research was a Quasi-Experiment study. It is research by treating respondent to find out the improvement. This research can be done without or with a control group [9]. The research design used a two-group pretest-posttest design. This research conducted on the first observation (pre-test). So, the researcher could test the changes that occurred by giving the questionnaire to the respondent (post-test) after treating fun cooking in healthy food toward computer-based. The sampling technique used Random Sampling technique. It means that the sample chosen randomly.

\subsection{Research instrument}

This research used an instrument in the form of a test. The multiple choice questions arranged based on the material lattice, with a category of scoring 10 points for correct answers and a score of 0 points for incorrect. The items made are ten multiple choice items with four image choices for each item. These questions measure children aged 
5-6 year's level of knowledge about healthy food. Before being tested on the sample, the instrument tested on ten children to find out the validity of the pre-test and posttest items. The cour ${ }_{t}$ compared with table $\mathrm{n}=10$ with a significant level of $\alpha=0.05$ so that the table is 0.632 . Criteria for item questions are declared valid if $r$ count $>r$ table. Instrument reliability carried out by internal reliability with the Cronbach alpha formula with SPSS 16. The reliability test results on the knowledge instrument obtained $r=0.91$, indicating the correlation coefficient in the high category in the range of $0.800-1.000$ [10].

\subsection{Data analysis technique}

\subsubsection{The implementation effect of educational games application analysis}

Normality tested first. Data normality test carried out by Kolmogorov Smirnov statistical test. The results obtained that data were normally distributed so that it could be carried out by the Paired Sample Test statistic test. A Wilcoxon statistical test performed for abnormal distribution data. Analysis with

Paired Sample Test and Wilcoxon test used to determine the significance of improvement in knowledge about healthy food before and after treatment at a 95\% confidence level using statistical software. If the $p$-value in the treatment group is obtained $<0.05$, the implementation fun cooking in healthy food toward computer-based influences improvement on knowledge of children aged 5-6 years.

\subsubsection{Improvement and effectiveness on implementation of fun cooking educational media analysis}

The effectiveness of using educational game products developed can increase in procedural cognitive children about making various healthy food menus using the experimental design (before-after). It can be seen in Table 1 [11].

The answer results obtained by calculating the percentage score to develop conclusions. It can be explained in Table 2 [10].

\subsubsection{Multivariate analysis}

Normality test used Chi-Square test with SPPS 16. Homogeneity test is done using the $\mathrm{F}$ test formula. If $\mathrm{F}_{\text {count }} \leq \mathrm{F}_{\text {table }}, \mathrm{H}_{0}$ is accepted. It means that the data is homogeneous. If 
TABLE 1: Experimental Design (before and after).

Pretest $\quad$ Treatment
$\mathbf{O}_{1}$

TABLE 2: Guidelines for Product Effectiveness Criteria.

\begin{tabular}{|l|c|l}
\hline No. & Interval & Criteria \\
\hline 1. & $76 \%-100 \%$ & High product effectiveness \\
\hline 2. & $25 \%-50 \%$ & Average product effectiveness \\
\hline 3. & $50 \%-75 \%$ & Low product effectiveness \\
\hline
\end{tabular}

$\mathrm{F}_{\text {count }}$ is $\geq \mathrm{F}_{\text {table, }} \mathrm{H}_{0}$ is rejected. It means that the data is not homogeneous. Test for two average differences, then use the Z-one-right- hand.

\section{Results}

\subsection{Description of media}

This Giziku educational game was designed and created using the MDLC development model. This Giziku educational game product is suitable for helping children aged 5-6 years in improving children's cognitive about nutrition, especially regarding balanced nutrition, introduction of food ingredients, and compiling a balanced menu. Giziku educational game uses CD as a storage medium.
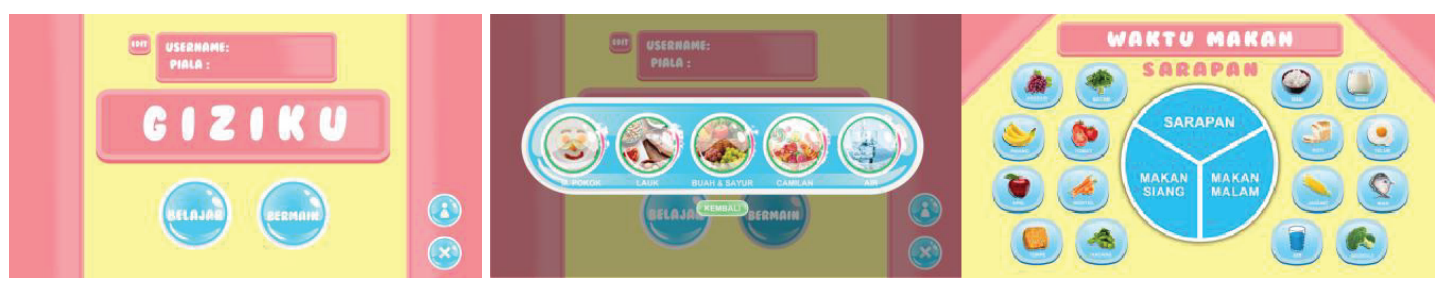

Figure 1: Media display ‘Giziku’. 


\subsection{Result analysis of implementing fun cooking toward computer-based on children aged 5-6 years' knowledge}

Data analysis consisted of knowledge value on children aged 5-6 years who are implementing fun cooking in healthy food toward computer-based. Student learning outcomes in the form of test scores and posttest were analyzed using a paired $T$ test. Before doing the $T$-Test, the normality tested first. It finds out whether it is normally distributed or not normally distributed. If the value is Sig. $>0.05$, the data is normally distributed. If the value is Sig. $<0.05$, the data is not normally distributed. On Kolmogorov, the significance of pre-testis 0.185 , and the significance of post-testis 0.061. Sig. $>0.05$, it means that the data is normally distributed. After analyzing using SPSS, it can be seen in the table above and finding the significance value. $\mathrm{T}_{\text {count }}=$ $6.184>>T_{\text {able }}=1.68709$, it indicates the independent variable (implementation of fun cooking toward computer-based) has an effect on the dependent variable (child's knowledge). Besides that, sig. 0,000 is less than 0.05, which means that $\mathrm{HO}$ is rejected, and automatically $\mathrm{H} 1$ is accepted. It concluded that there is significant influence between knowledge in children aged 5-6 years before and after using fun cooking in healthy food toward computer-based.

\subsection{Effectiveness result of fun cooking media in healthy food toward computer-based on child's knowledge aged 5-6 years}

Testing respondent is the final stage of testing. An instrument for respondents used a Guttman scale questionnaire consisting of 10 student respondents. Based on the instruments that have been filled in by the respondents, the data will be processed into a percentage of the feasibility of each question item. In brief, the implementation of fun cooking in healthy food toward computer-based on children's knowledge has an average value of $96 \%$ than expected with high media effectiveness.

\subsection{Result analysis of differences child's knowledge aged 5-6 years who implemented fun cooking in healthy food toward computer-based}

The normality test of chi-squares performed on Delta from the control class and instrument class. For the results of the normality test, the control class data produced $\chi^{2}$ count that is 14.58 with $\chi^{2}$ table $=15.51$, so that $\chi^{2}$ counts $\leq \chi^{2}$ table. Ho is rejected. It concluded that the data is normally distributed. Then, to test the data normality of 
experimental class produced $\chi^{2}$ count that is 21.22 with $\chi^{2}$ table $=15.51$, so that $\chi^{2}$ counts $\geq \chi^{2}$ table. Ho is rejected. It concluded that the data is not normally distributed. In brief, the control class and experimental class data are not normally distributed. The results of the normality test showed a significance value of 0.05 . In the control class shows the value of $p=0.068>0.05$ means that $\mathrm{Ho}$ is accepted, the data is normally distributed. While the experimental class shows the value of $p=0.007<0.05$ means that the data is not normally distributed.

From the results of the homogeneity test, variance obtained Fcount 0.621 with the numerator $=(37-29)$ and the denominator $=(38-1)$. Based on the numerator $=8$, and the denominator $=37$, with the error level set $=5 \%$, Ftable $=2.20$ (between numerators 8 and 37 ) is obtained. Thus, Fcount $\leq$ Ftable so Ho is accepted so that it concluded that "data/variance is homogeneous." The value of $p$ is $0.753>$ of the significance value of 0.05 then the data is homogeneous.

The test result of Mann Whitney conducted on a sample of more than 30. A normal curve of formula $\mathrm{Z}$ is used. Zcount is -2.89 . Whereas, $\mathrm{Z}$ table with $\alpha=0.05$ is generated Ztable $=-1.96$. Then, $-Z$ count $<-Z$ table. $\mathrm{Ho}$ is rejected, and $\mathrm{Ha}$ is accepted. It can be seen from the significance value of $0.004<0.05$, which means there is a significant difference. To sum up, there is a significant difference in a fun cooking in healthy food by using old media in the form of images and new media in the form of computer-based. The knowledge of fun cooking in healthy food that used computer-based is better than images.

\section{Discussion}

Paired $t$ sample test results showed count $=6.184>$ from $t$-table $=1.68709$. It indicates that the independent variable affects the dependent variable. Besides that, sig. 0,000 is less than 0.05. It means that $\mathrm{HO}$ is rejected, and $\mathrm{H} 1$ is accepted. In conclusion, there is a significant influence on knowledge in children aged 5-6 years before and after implementing fun cooking in healthy food toward computer- based. According to Randi Catono, educational games are creative activities related to the creation, production, and distribution of computer and video games that are entertainment, agility, and education [12]. Educational games are one form of the game that is used as a means of supporting learning, both formally and non-formally. An educational game is a computer game that contains educational material to help children learn fun. Through this educational game, students will be more eager to learn because it is done while playing, so it can improve children's learning outcomes, especially to improve children's 
ability to add numbers. Treatment through educational games is only given during intervention. After the observation, it completes the measurement of the ability of the child will be done by using the percentage of total questions answered correctly. Based on the results of Fitri Yeni's research in 2013, the results of data analysis that have been explained previously, can be proven that giving intervention through educational games is effective in increasing the number addition ability for DII class learning difficulties at MIN Koto Luar, Pauh District [13].

Besides having a negative impact on children, the game also has many positive effects. One of them is using educational games. In addition to utilizing technological developments, educational games also use elements in the game that can attract the attention of the younger generation. Educational games are expected to help in the introduction of existing culture and can be used as an insight to children. With the use of educational games as an introduction to culture can contain material textually, audio and visual. According to Felicia compared to traditional methods, learning using educational games can not only provide motivation, but also make children learn by playing, and can improve skills that are still difficult to develop in traditional methods [14].

Even not a few who play games are a hobby, as the results of a survey conducted 91\% of children aged 2-17 years play video games and computer games [15]. The use of educational games as a learning medium for the introduction of regional culture is felt to be suitable because it can take advantage of developing the technology. According to Griffiths games can provide innovative ways of learning [16]. Students are more intrigued to play a role in learning. The link between increased motivation for student activity when the application of game-based learning is in line with Park which examines the relationship between student motivation and activity in game-based learning with the results of students who are given high-level activity games tend to have the high motivation [17].As stated by Busran, game applications can be educational. Of the two informants explained when children use games such as counting, reading children will easily understand and can hone children's thinking power. Children will also easily memorize something with applications on the computer because the computer has an attraction for children aged 4-5 years [18]. However, playing the computer makes children indifferent to the surrounding environment. Of all the informants explained that the children while playing the computer, children will be difficult to call and tend to be quiet. Children must be called more than $1 x$ to respond to the child's environment.

Computer to children's skills average value is $96 \%$ than expected with high media effectiveness. Nutrition education programs are the core of essential services that 
aim to overcome nutritional problems. By providing nutritional messages to optimize nutritional status through behavioral changes in food selection and provision. It reflected in nutritional education in Hong Kong schools that designed attractively and practical implementation in instilling healthy food habits [19]. Also, the factors that influence a person's nutrition are nutritional intake itself, where nutritional intake will have a significant impact on human health [20].

Based on Mann-Whitney test results with a sample of more than 30 , the normal formula $\mathrm{Z}$ is used. Zcount is $-\mathbf{2 . 8 9}$. Whereas, $\mathrm{Z}$ table with $\alpha=0.05$ generated Ztable $=-1.96$ Then, $-\mathrm{Z}$ counts <-Ztable. $\mathrm{H}_{o}$ is rejected and $\mathrm{Ha}$ is accepted. It means that there is a significant difference in the use of old media using images and new media using computer-based educational games about healthy food. Knowledge that uses computer-based educational game media about healthy foods is better than the use of media in the form of images. This research is in line with Saputra Dahniman, who states that there is a change in the provision of nutritional education through the media on changes in consumption of fruit and vegetables in junior high school students [21]. The impact of nutritional education in California states that coordinated nutritional education can significantly influence food consumption toward a better selection of healthy foods [22]. Providing nutritional information on nutritional education can promote healthy food choices [23]. Dian Wahyu Putra et al. said about educational games for early childhood. The use of smartphones, iPad, Tablet PCs, and the like in everyday life is increasingly prevalent. Starting from well-known brands to ordinary, and sophisticated to simple ones are increasingly used. Various reasons become a magnet for all people in its use. Lightweight, easy to carry, practically the main reason for its use. Also, there are many game features that not only play entertainment, but there are many games to hone the mind and logic that can introduce material to be more interesting to be accepted and understood especially by children who are still at an early age. Early childhood between the ages of 3-6 years is in the Golden Period of their brain development. In this age, they are at the most rapid growth and development both physically and mentally. Therefore, the author makes an educational game based on the Android operating system in the hope that children can immediately use the game application and gain more knowledge and change learning patterns so that they are not bored and bored [24].

According to Erri Wahyu Puspitasari, the use of smartphones, iPad, Tablet PCs, and the like in everyday life is increasingly prevalent. Starting from well-known brands to ordinary, and sophisticated to simple ones are increasingly used. Various reasons become a magnet for all people in its use. Lightweight, easy to carry, practically the main reason for its use. Also, many game features are not only playing entertainment, 
but there are many games to hone the mind and logic that can introduce material to be more interesting to be accepted and understood especially by children who are still at an early age [25]. In general, the educational games applied in this study have positive values on children's learning interests. It has an impact on increasing children's learning interest. With the implementation of educational games, children are more eager to learn and understand learning material. Because in essence, early childhood is indeed in the stage of playing. So that any activity is carried out by playing method can attract children to learn.

The results of this study supported by research conducted by Petrovska, Sivevska, and Cackov from the University of Goce Delcev. The researchers stated that the game could meet the biological and psychological needs of children and contribute to their mental, emotional, social and moral development. Games are an essential form of entertainment for children and adults, where children organize independently and have special meaning for education. They are powerful tools for education because through games children gain knowledge, enrich their experiences, and develop skills and habits. Although the research conducted by researchers with the research conducted by Petrovska, Sivevska, and Cackov differed in the dependent variable, both of these studies found the benefits of games for education, unusually early childhood education. So that the hypothesis used in this study can be accepted, namely active educational games to increase interest in learning early childhood, especially kindergarten children in group B in Aisyiyah Nusukan 1 and three kindergartens Surakarta 2015/2016 Academic Year [26].

\section{Conclusion}

Based on the results of the research that has been done, it concluded that: (1) There is significant influence between knowledge in children aged 5-6 years before and after implementing fun cooking in healthy food toward computer-based. (2) The implementation of fun cooking in healthy food toward computer-based on the child's knowledge aged 5-6 years has a high level of media effectiveness. (3) There is a significant difference in implementing fun cooking in healthy food according to old media using images and new media using computer-based. The implementation fun cooking in healthy food toward computer-based is better than images. 


\section{Funding}

This study was funded by the Applied Research Grant Program, Higher Education for the Institutional National Strategic Research Scheme for 2018 Fiscal Year.

\section{Acknowledgment}

The authors would like to thank the Indonesian Ministry of Research and Technology, the Institute of Research and Community Service of UNJ and Faculty of Engineering - State University of Jakarta for providing financial support to the research as well as some of the parties listed in the references in research results writing as a reference for previous theories and data research. And also at FT-UNJ as the organizer of 2018 ICTVET.

\section{Conflict of Interest}

The authors have no conflict of interest to declare.

\section{References}

[1] Mutiah, D. (2010). Psikologi Bermain Anak Usia Dini. Jakarta: Kencana

[2] Martono, N. (2015). Metode Penelitian Sosial. Jakarta: PT. Raja Grafindo Persada.

[3] Desiningrum, D.R. \& Prihatsanti, U. (2011). studi diskriptif engenai frekuensi menonton televisi dan main game elektronik pada anak di Semarang. Jurnal Psikologi Pitutur, vol. 1, no. 2, 72-76.

[4] Umayya, S.H. (2006). Hubungan antara emotion focused coping dengan prokratinasi akademik pada mahasiswa.Essay. Yogyakarta: Fakultas Psikologi Universitas Islam Indonesia.

[5] Devianti, A. (2013). Panduan Lengkap Mencerdaskan Otak Anak usia 1-6 tahun. Yogyakarta: Araska.

[6] Tedjasaputra, M. S. (2001). Bermain, Minat dan Permainan untuk Pendidikan Usia Dini. Jakarta: Grasindo.

[7] Riska, N. and Annis, K. (2017). Media Funcooking Development Based On Multimedia, UNESA, vol. 1, no. 1 (2017): The 1th International Conference on Education Innovation (ICEI) 
[8] Demitri, A. (2015). Pengaruh Pendidikan Gizi Tentang Pola Makan Seimbang Melalui Game Puzzle dan Gambar Animasi Terhadap Peningkatan Pengetahuan Anak SDN 067690 Kota Medan. Essay. Fakultas Kesehatan Masyarakat. Universitas Sumatera Utara, Medan.

[9] Notoatmodjo, S. (2012). Metodologi Penelitian Kesehatan. Jakarta: Rineka Cipta.

[10] Arikunto, S. (2010). Prosedur Penelitian, Suatu Pendekatan Praktik. Jakarta: PT Rineka Cipta.

[11] Sugiyono. (2016). Metode Penelitian Kuantitatif Kualitataif dan Kombinasi (Mixed Methods). Bandung: Alfabeta.

[12] Cartono, R. (2013). Jagat Permainan Interaktif. Jakarta: PT. Bumi Aksara.

[13] Fitri Yeni, Yarmis Hasan, and Tarmansyah. (2013). Efektifitas Game Edukasi Untuk Meningkatkan Kemampuan Penjumlajan Bagi Anak Kesulitan Belajar Di Min Koto Luar, Kecamatan Pauh. E-JUPEKhu (JURNAL ILMIAH PENDIDIKAN KHUSUS). Volume 2 no. 3, September 2013, pp. 501-513. http://ejournal.unp.ac.id/index.php/ jupekhu

[14] Ariesa, F. N. (2011). Analisis kelayakan Restrukturisasi Mesin Pabrik Gula Kremboong, Kabupaten Sidoarjo, Jawa Timur. Essay. Departemen Agribisnis Fakultas Ekonomi dan Manajemen Institut Pertanian Bogor: Bogor.

[15] Granic, I., Lobel, A., \& Engels, R. C. M. E. (2014). The benefits of playing video games. American Psychological Association, vol. 69, pp. 66-78.

[16] Griffiths, M. (2005). Video games and health. British Medical Journal, vol. 331, p. 122.

[17] Park, H. (2012). Relationship between Motivation and Student's Activity on Educational Game. International Journal of Grid and Distributed Computing, 1(5): 101-114. Tersedia di http://sersc.org [diakses 24-02- 2018].

[18] Busran., M. P. (2012). Analisa Komputasi Enkripsi dan Dekripsi Data, Gambar, Teks, dan Audio dengan Menggunakan Algoritma RC4 Berbasis Visual Basic 6.0. Jurnal Teknologi Informasi dan Pendidikan.

[19] Yeung, D. S., Cloete, I., \& Shi, D. (2010). Sensitivity Analysis for Neural Network. Glasgow: Springer.

[20] Rubio-López, N., Morales-Suárez-Varela, M., Pico, Y., et al. (2016). Nutrient intake and depression symptoms in Spanish children: The aniva study. International Journal of Environmental Research and Public Health, 13(3), 352.

[21] Mhd. Dahniman Saputra, Yulia Wahyuni, and Rachmanida Nuzrina. (2016). Giving Effect Of Nutritional Education Through Video And Leaflet Media On Fruit And Vegetable Consumption Of Changes In Al Chasanah Junior High School Students In 2016. Essay. Universitas Esa Unggul. 
[22] Ritchie, B., and Brindley, C. (2005). ICT Adoption By Smes: Implications for Relationships And Management. New Technology, Work and Employment, 20(3), 205-217.

[23] Freedman, M. R., \& Connors, R. (2010). Point-of-purchase nutrition information influences food-purchasing behaviors of college students: a pilot study. Journal of the American Dietetic Association, 110(8), 1222- 1226.

[24] Dian Wahyu Putra, A. Prasita Nugroho, \& Erri Wahyu Puspitarini. (2016). Game Edukasi Berbais Android Sebagai Media Pembelajaran Untuk anak Usia Dini. Jurnal Informatika Merdeka Pasuruan, vol. 1 halaman 47.

[25] Puspitarini, Erri, dkk. (2016). Game Edukasi Berbasis Android Sebagai MediaPembelajaran Untuk Anak Usia Dini. Pasuruan: Universitas Merdeka.

[26] Petrovska, S., Sivevska, D., \& Cackov, O. (2013). Role of the Game in the Development of Preschool Child. Lumen Research Center, 880-884. 